\title{
Road anger expression-Changes over time and attributed reasons
}

\author{
Møller, M.; Haustein, Sonja
}

Published in:

Accident Analysis and Prevention

Link to article, DOI:

10.1016/j.aap.2018.06.013

Publication date:

2018

Document Version

Peer reviewed version

Link back to DTU Orbit

Citation (APA):

Møller, M., \& Haustein, S. (2018). Road anger expression-Changes over time and attributed reasons. Accident Analysis and Prevention, 119, 29-36. https://doi.org/10.1016/j.aap.2018.06.013

\section{General rights}

Copyright and moral rights for the publications made accessible in the public portal are retained by the authors and/or other copyright owners and it is a condition of accessing publications that users recognise and abide by the legal requirements associated with these rights.

- Users may download and print one copy of any publication from the public portal for the purpose of private study or research.

- You may not further distribute the material or use it for any profit-making activity or commercial gain

- You may freely distribute the URL identifying the publication in the public portal

If you believe that this document breaches copyright please contact us providing details, and we will remove access to the work immediately and investigate your claim 
Road anger expression - Changes over time and attributed reasons

M. Møller* \& S. Haustein

Technical University of Denmark, Department of Management Engineering, DK-2800 Kgs.

Lyngby, Denmark

*Corresponding author. Tel. +45 45256537

E-mail address: mette@dtu.dk 
Abstract

Based on the results from three independent surveys conducted in Denmark in 2005, 2008 and 2016, this paper provides an overview of the development of road anger expression in general and in demographic sub-groups of road users. In addition, it investigates how people explain own and other people's road anger expression and if attributed reasons are related to demographic factors and level of anger expression measured based on the short form of the driving anger expression inventory (DAX-short). From 2005 to 2016 the percentage of people involved in anger expression incidents increased particularly in the densely populated Capital Region of Denmark. The increase was most pronounced for "yelling” and "threatening”, and particularly in densely populated areas. Men were more often involved than women both as aggressor and as victim, but the gender difference decreased from 2008 to 2016. Generally, own anger expression was more often explained with getting frightened (non-hostile attribution), while anger expression by other road users was more often explained by not being able to control own anger or by wanting to show that one made a mistake (hostile attribution). However, people scoring high in aggressive anger expression often explained own anger expression by "not being able to control anger”, thereby indicating self-reflection and a potential for behavioural change. Behavioural reactions to being frightened are to some extend mistakenly interpreted as expressions of anger by other road users. Results indicate that cognitive and behavioural interventions, possibly as part of the driver education, are relevant to reduce aggressive anger expression in traffic.

Keywords: Driving anger; aggressive driving; anger expression, DAX 
1. Introduction

Knowledge on anger and anger expression in traffic is important not only because being a victim of other road users' anger expression is unpleasant and has long lasting negative impact (Novaco, Stokols, \& Milanesi, 1990), but also because it poses a risk towards road safety (Wickens, Mann, Lalomiteanu, \& Stoduto, 2016).

Anger and anger expression in traffic has been addressed in numerous studies using a variety of methods such as diaries (e.g., Wickens, Roseborough, Hall, \& Wiesenthal, 2013), observations (e.g., Shinar \& Compton, 2004), naturalistic driving (e.g., Precht, Keinath, \& Krems, 2017), simulations (e.g., Deffenbacher, Deffenbacher, Lynch, \& Richards, 2003), surveys (e.g., Berdoulat, Vavassori, \& Sastre, 2013; Hennessy, 2016; Parker, Lajunen, \& Summala, 2002), social media postings (e.g., Stephens, Trawley, \& Ohtsuka, 2016), and meta-analysis (e.g., Bogdan, Mairean, \& Havarneanu, 2016; Nesbit, Conger, \& Conger, 2007; Zhang \& Chan, 2016). Most studies focus on driver anger and so far, only few studies have addressed road anger in relation to other transport modes. Examples of the few exceptions include a study comparing anger levels of motorcyclists and drivers (Rowden, Watson, Haworth, Lennon, Shaw, \& Blackman, 2016), and a study comparing anger expression among drivers and cyclists (Møller \& Haustein, 2017). In addition, a few studies have explored anger expression among professional drivers for example a study by Feng et al. (2016) on Chinese bus drivers, and a study by Sullman, Stephens, and Kuzu (2013) on Turkish taxi drivers.

The concept of driver anger regards anger triggered off while driving and originally stems from the work of Deffenbacher and colleagues and their development of the Driving Anger Scale (Deffenbacher, Oetting, \& Lynch, 1994) and later on the Driving Anger Expression Scale (DAX) (Deffenbacher, Lynch, Oetting, \& Swaim, 2002). Since then, the DAX has become one of the most commonly used measures of anger expression while driving (Stephens \& Sullman, 2014), and has been used to identify differences in anger expression based on individual factors such as age, gender, personality and demographic factors (see Sullman, 2015).

Over the years, a relationship between anger and aggressive driving has been established and confirmed many times (e.g., Bogdan, Mairean, \& Havarneanu, 2016; Dahlen, Martin, Ragan, \& Kuhlman, 2005; Deffenbacher, Lynch, Filetti, Dahlen, \& Oetting, 2003; González-Iglesias, GómezFraguela, \& Luengo-Martín, 2012; Lajunen \& Parker, 2001). Furthermore, recent studies show a clear relationship between anger and increased accident risk in traffic (Kaiser, Furian, \& 
Schlembach, 2016; Wickens, Mann, Lalomiteanu, \& Stoduto, 2016) thereby confirming the relevance to the area of road safety. This is further supported by a recent study by Precht, Keinath, and Krems (2017) showing that the accident risk related to anger is based on deliberate and therefore changeable behaviours as opposed to unintended errors and mistakes.

To prevent risk increasing anger expressions, further knowledge is needed not only about the traffic situations in which anger appears, and the people likely to express their anger in an aggressive way, but also about the underlying individual motivations and psychological attributions. It is well known, that the interpretation of a situation influences behaviour so that hostile attributions are more likely to lead to aggressive behaviours compared to non-hostile attributions (e.g., Crick \& Dodge, 1996; Lemerise \& Arsenio, 2000). However, this knowledge has only been applied to the area of road traffic anger to a very limited extend. A scenario-based study by Yagil (2001) based on male drivers showed that aggressive behavioural reactions were positively related to negative expectations and beliefs about other road users, and that more hostile attributions were directed towards male drivers compared to female drivers. In 2006 Britt and Garrity (2006) looked into different types of attributional processing related to anger-provoking traffic situations and their relation to anger expression. Results showed that higher levels of anger expression and aggressive behaviour were found when participants attributed the anger expression to stable characteristics of the other road user. In addition, attributing hostile intentions to the anger expressing road user was related to increased aggression. Lennon and Watson (2011) found that similar behavioural expressions may have different underlying motives, and a study by Lennon, Watson, Arlidge and Fraine (2011) showed that victims and aggressors focus on different aspects in their interpretation of the situation.

In recent years, anger expression has gained increasing popularity as a research field (Sullman, 2015) and media topic (e.g., Smart \& Mann, 2002; Li, Yao, Jiang, \& Li, 2014). Whether or not this is just a result of increased awareness of the issue supported by its value to the media as a dramatic and unpredictable event (Roberts \& Indermaur, 2005), increased perceived relevance due to increased amount of daily transport (e.g., Galovski \& Blanchard, 2004), or an actual increase in the phenomenon is unknown as very few longitudinal studies exist. However, results from a study by Vanlaar, Simpson, Mayhew, and Robertson (2008) indicate unchanged levels of anger expression, although the large majority believe that the frequency of aggressive driving has increased over the past years. Others have suggested that the improved safety features of modern cars such as airbags 
may mask a possible increase in anger related collisions due to reduced injury (Davis \& Smith, 1998 in Burns \& Katovich, 2003).

On this background, the purpose of this study was twofold: First, to provide an overview of the development of road anger expression in Denmark from 2005 to 2016 and to see to what extent possible changes differ in specific sub-groups of the population. Second, to investigate how people explain their own anger expression as well as the anger expression of others, to what extent both attributions are related to each other, to demographic variables and to anger expression measured with a standardised instrument (DAX). The results will be relevant for the development of information and communication strategies aiming at a reduction of road anger expression in Denmark and other countries.

\section{Method}

\subsection{Procedure and participants}

Data in 2016 were collected based on an online panel ("Danmarkspanelet”) by the market research institute EPINION on behalf of the Danish Road Safety Council. The panel consists of 244,568 members covering all regions of Denmark. Panel membership is rewarded with regular participation in lotteries (see Epinionglobal.com for details). In September 2016, a total of 2000 people aged between 18 and 75 years living in Denmark completed an online questionnaire. The results of this survey were compared with results from two earlier surveys conducted in 2005 (DST \& DKR, 2005) and 2008 (DKR, 2009) by the Danish Crime Prevention Council in cooperation with Statistics Denmark. In both studies, data were collected based on telephone interviews as part of a monthly omnibus survey based on random samples of the population drawn from the person register among all people between 16 and 74 years of age living in Denmark. In 2005, a random sample of 1500 people was drawn from the register, 1215 individuals were contacted (net sample), and 965 (79\% of the net sample) participated in the survey (DST \& DKR, 2005). For the survey in 2008 it is only reported that a similar procedure as in 2005 was used (DKR, 2009). The study in 2016 was not done based on telephone interviews for mainly two reasons: First, the number of people with conventional telephone network is decreasing (Energistyrelsen, 2016) and the remaining population may not be representative. At the same time, internet access and use in Denmark is high (Lauterbach, 2015) and the willingness to participate in online interviews as 
compared to telephone interviews is increasing. Second, the budget for the study was limited and did not allow for the conduction of telephone interviews.

Table 1 describes the samples of the three surveys. Data in 2016 were weighted by age, gender and region to increase the representativeness for Denmark and to increase the comparability of the three data sources. For data collected in 2005 and 2008 it is only reported that data were weighted and that the sample can be regarded as representative for the population aged 16-74 in Denmark after the weighting (DST \& DKR, 2005). Participants' level of education in 2016 was a bit higher than in the general population of Denmark. In Denmark, 20.7\% of the population aged 20-69 finalised school after the $9^{\text {th }}$ or $10^{\text {th }}$ grade without any further education (=basic education), while it was only 9.3\% in the survey; $10.4 \%$ of the Danish population had a long further education (5 years or more, e.g. master degree), while it was $18.1 \%$ of the survey population (own calculations based on Statistics Denmark, http://www.statistikbanken.dk).

Table 1: Sample description of the survey in 2005, 2008 and 2016

\begin{tabular}{|c|c|c|c|c|}
\hline & & $\begin{array}{l}\text { Survey } 2005 \\
\qquad N=965\end{array}$ & $\begin{array}{l}\text { Survey } 2008 \\
\qquad N=930\end{array}$ & $\begin{array}{c}\text { Survey } 2016 \\
\quad N=2000\end{array}$ \\
\hline Gender & Male & 50.5 & 51.1 & 47.6 \\
\hline \multirow[t]{3}{*}{ Age } & $16-29^{\mathrm{a}} / 18-29^{\mathrm{b}}$ & 17.8 & 16.5 & 18.0 \\
\hline & $30-49$ & 40.4 & 36.6 & 31.5 \\
\hline & $50-74^{\mathrm{a}} / 50-75^{\mathrm{b}}$ & 41.8 & 47.0 & 50.6 \\
\hline \multirow[t]{4}{*}{ Education } & Basic education & & & 9.3 \\
\hline & Short further education & & & 29.9 \\
\hline & Medium further education & & & 42.7 \\
\hline & Long further education & & & 18.1 \\
\hline \multirow[t]{5}{*}{ Region } & Capital & & 25.1 & 30.6 \\
\hline & Zealand & & 16.2 & 13.9 \\
\hline & Southern & & 22.9 & 22.1 \\
\hline & Central & & 24.1 & 23.0 \\
\hline & Northern & & 11.7 & 10.4 \\
\hline
\end{tabular}

\subsection{Material}

In all three surveys, participants were asked about their involvement in five specific types of anger expression in traffic as victim and/or aggressor within the past 12 months: (1) "yelling at other road users/being yelled at”; (2) "giving/getting the finger”; (3) "threatening others/being threatened"; (4) "hitting or kicking other persons vehicle/own vehicle being hit or kicked" and (5) "hitting or 
kicking a person/being hit or kicked" (see Table 3). These five situations reflect the taxonomy of road anger behaviours suggested by Smart and Mann (2002) apart from causing death of other road users, which was not requested. If involved in any of the five situations, participants were further asked how many times it had happened and which transport mode they and the counterpart used in the most recent situation. From the surveys in 2005 and 2008, the data was not available but only the documentation of results. The five specific situations were originally chosen because they represented different categories of anger expression (verbal expressions, physical expressions, and expressions involving a vehicle). Moreover, these situations were often referred to in the Danish media based on narratives but without any statistical evidence, which the first survey aimed to provide.

The questionnaire used in 2016 additionally included a short form of the Driver anger expression inventory (DAX, Stephens \& Sullman, 2014) translated to Danish. The Danish DAX showed the same factor structure as the original DAX (Møller \& Haustein, 2017). In contrast to the involvement in the five specific situations described above, the DAX measures more general dimensions of road anger expression. While the five specific situations are partly covered by "total aggressive expression”, the DAX additionally measures “adaptive/constructive expression” (e.g., "I tell myself to ignore it", see Table 2). Both DAX scales have been found related to "yelling” and "giving the finger" (see Møller \& Haustein, 2017), two of the five specific situations of road anger expression measured in this study. The three other specific situations were not included in the calculation due to too frequent cases. The DAX scales were calculated as means of the items included in Table 2. The two scales have acceptable internal consistencies as shown by Cronbach's alpha above .8 . 
Table 2: DAX scales of "total aggressive expression” and "adaptive/constructive expression”

\begin{tabular}{|c|c|c|c|}
\hline DAX items & Mean & SD & $\begin{array}{c}\text { Cronbach's } \\
\text { alpha }\end{array}$ \\
\hline Total aggressive expression & & & .85 \\
\hline I make negative comments about the road user aloud & 2.38 & 0.93 & \\
\hline I swear at the other road user aloud & 2.25 & 0.96 & \\
\hline I yell at the other road user & 1.49 & 0.79 & \\
\hline I get out/of the car/bicycle and tell the other driver off & 1.08 & 0.44 & \\
\hline I get out/of the car/bicycle to have a physical fight & 1.07 & 0.43 & \\
\hline I roll down the window to communicate my anger & 1.15 & 0.52 & \\
\hline I try to scare the other road user & 1.10 & 0.46 & \\
\hline I drive right up to the other road user & 1.29 & 0.61 & \\
\hline I do to the other road users what they did to me & 1.24 & 0.58 & \\
\hline I drive a lot faster & 1.44 & 0.76 & \\
\hline Adaptive/constructive expression & & & .86 \\
\hline I think of positive solutions to deal with the situation & 3.35 & 1.21 & \\
\hline I tell myself it's not worth getting mad at & 3.66 & 1.10 & \\
\hline I tell myself it's not worth getting involved & 3.83 & 1.16 & \\
\hline I accept there are frustrating situations & 3.67 & 1.03 & \\
\hline I tell myself to ignore it & 3.69 & 1.06 & \\
\hline
\end{tabular}

Note: 1 = never; 5 = always; $N=1603$. People who answered to never drive did not get the respective questions.

Participants in 2016 were further asked to indicate their level of agreement to five attributions to anger expressed by themselves and other road users (see Table 10) on a 5-point Likert scale (1 = “totally disagree”; 5 = “totally agree”). Inspired by the work of Britt and Garrity (2006) and Yagil (2001) the attributions were selected to cover hostile ("show me that I made a mistake") and nonhostile ("got frightened") attributions as well as attributions related to the road user ("unable to behave" and "unable to control anger") and attributions related to more general aspects of the life of the road user ("letting off steam").

Finally, the following demographic variables were requested: age, gender, income, education, and postal code.

\subsection{Analysis}

Involvement in the five situations of road anger were compared between the three survey waves based on $\mathrm{Chi}^{2}$-tests. Also subgroup-specific differences in the involvement of road anger were tested by $\mathrm{Chi}^{2}$-tests. Differences between attributed reasons for own and others' aggressive 
behaviour were tested by paired t-tests. Differences in the level of agreement to different reasons based on demographic categories were tested based on t-tests and relations to the DAX scales were tested based on correlation (Pearson).

\section{Results}

\subsection{Changes in anger expression over time}

About one third of the 2016 sample (35\%) reported to have experienced at least one of the five requested expressions of anger within the past twelve month as a victim, while it was only $24 \%$ in the survey conducted in 2008. About one quarter (26\%) has shown one of these anger expressions towards other road users, while it was $16 \%$ in 2008 . While $57 \%$ of the 2016 sample was neither victim nor aggressor, $17 \%$ was both victim and aggressor, $17 \%$ was victim only and $9 \%$ was aggressor only. Table 3 shows the percentages for each requested situation of road anger expression in 2016 and the comparable values for 2008 and 2005, if available. When we compare the values, we find that anger expression has rather decreased from 2005 to 2008, while it has increased both when comparing 2005 and 2016 values and when comparing 2008 and 2016 values. However, when comparing data from 2005 and 2016, not all increases are statistically significant. While the percentage of people involved in anger expression situations generally increased, there is quite some variation over time and situations. Increases are most pronounced for yelling at other road users and threatening others.

Table 3: Involvement in different road anger situations as victim and as aggressor in the past 12 months

\begin{tabular}{|c|c|c|c|c|c|}
\hline \multirow{2}{*}{ Situation } & \multicolumn{3}{|c|}{ Involvement (\%) } & \multirow{2}{*}{$\begin{array}{c}\text { Change } \\
\text { from } 2005 \\
\text { to } 2016 \\
\text { Chi }^{2} \text { test; } p\end{array}$} & \multirow{2}{*}{$\begin{array}{c}\text { Change } \\
\text { from } 2008 \\
\text { to } 2016 \\
\text { Chi }^{2} \text { test; } p\end{array}$} \\
\hline & 2005 & 2008 & 2016 & & \\
\hline I was yelled at by other road users & 16.4 & 13 & 22.7 & $<.001^{*}$ & $<.001^{*}$ \\
\hline I got the finger & 22.9 & 16 & 21.1 & .265 & $.001 *$ \\
\hline I was threatened by other road users & 4.3 & 3 & 7.0 & .004 & $<.001^{*}$ \\
\hline My vehicle was hit by other road users & 3.2 & n.a. & 4.6 & .073 & n.a. \\
\hline I was hit by other road users & 0.5 & 0 & 0.8 & .359 & .006 \\
\hline I yelled at other road users & 11.8 & n.a & 18.7 & $<.001^{*}$ & n.a. \\
\hline I gave the finger & 10.1 & 7 & 13.3 & $<.001^{*}$ & $<.001^{*}$ \\
\hline I threatened other road users & 0.7 & n.a & 1.3 & 0.143 & n.a. \\
\hline I hit others' vehicle & 0.3 & n.a & 1.6 & $.002 *$ & n.a. \\
\hline
\end{tabular}


I hit other road users
Note. Data is weighted; *significant $(p<.05)$ after Bonferroni correction. Accounting for 15 comparisons, the $p$-value has to be $<$
0.003 for the test result to be statistically significant according to the original level of significance $(p<.05)$.

When we compare how often people were exposed to the two most frequent forms of anger expression in 2005 and 2016, we find that people were more often exposed to anger expression in 2005 than 2016 (see Table 4). Unfortunately, this data was not available for 2008. The frequency of the other three situations is not reported as it would be based on too few cases.

Table 4: Involvement in the most frequent anger expression situations in 2005 and 2016

\begin{tabular}{lccccccccc}
\hline Situation & \multicolumn{8}{c}{ Frequency of involvement in the past 12 months } \\
& & $1 \mathrm{x}$ & $2 \mathrm{x}$ & $3 \mathrm{x}$ & $\begin{array}{c}\text { 4 or } \\
\text { more }\end{array}$ & $\begin{array}{c}\text { don't } \\
\text { know }^{\mathrm{a}}\end{array}$ & Mean & $n$ \\
\hline I was yelled at by other road users & 2005 & 36.1 & 26.7 & 14.4 & 21.8 & 1.0 & 7.2 & 150 \\
& 2016 & 54.2 & 25.3 & 8.3 & 12.2 & - & 2.5 & 455 \\
I got the finger & 2005 & 41.5 & 23.5 & 11.2 & 23.8 & 0.0 & 5.3 & 212 \\
& 2016 & 58.9 & 22.3 & 5.9 & 12.9 & - & 2.3 & 421 \\
I yelled at other road users & 2005 & 36.3 & 29.6 & 4.6 & 28.7 & 0.8 & 5.9 & 103 \\
& 2016 & 45.6 & 22.7 & 7.4 & 24.4 & - & 5.0 & 373 \\
I gave the finger & 2005 & 47.5 & 26.3 & 6.2 & 20.1 & 0.0 & 3.6 & 93 \\
& 2016 & 51.6 & 22.4 & 7.1 & 18.9 & - & 4.0 & 265 \\
\hline
\end{tabular}

Note. Data in this table for 2005 and 2016 is weighted; for 2008 this information was not documented. ${ }^{a}$ In 2016 "don't know" was not included as answer category.

Table 5 shows if people were involved in anger expression situations as victim or aggressor divided by age and gender. In 2008, the involvement in anger expression decreases with increasing age. However, in 2016 the age group 30-39 was exposed to and expressed most aggression. This may indicate a cohort effect as people who were aged 30-39 in 2016, were in the lowest age group in 2008 - or it may indicate that the new generation is less aggressive (when taking the general increase of road rage into account). We find the lowest increase from 2008 to 2016 when comparing the youngest age group in both years, and the highest increase when comparing the second youngest age group (30-39 y.). When looking at gender differences, we find that differences between men and women are smaller in 2016 than in 2008. However, when testing for statistical significance, we find that women both in 2008 and 2016 were more often victim of aggression than men, while the gender difference is not significant for expressing anger.

Table 5: Involvement in anger expression as victim and as aggressor across all situations by age and gender.

Exposed to road anger (victim) $\quad$ Expressed road anger (actor)

$2008 \quad 2016 \quad 2008 \quad 2016$ 


\begin{tabular}{|c|c|c|c|c|c|}
\hline \multirow[t]{6}{*}{ Age } & -29 & $30.6 \%$ & $35.5 \%$ & $26.1 \%$ & $28.2 \%$ \\
\hline & $30-39$ & $24.3 \%$ & $40.4 \%$ & $15.6 \%$ & $34.0 \%$ \\
\hline & $40-49$ & $25.7 \%$ & $34.8 \%$ & $18.7 \%$ & $27.2 \%$ \\
\hline & $50-59$ & $23.0 \%$ & $36.1 \%$ & $9.1 \%$ & $24.7 \%$ \\
\hline & $60+$ & $14.6 \%$ & $29.0 \%$ & $7.5 \%$ & $17.6 \%$ \\
\hline & $p\left(\right.$ Chi $^{2}$-test $\left.{ }^{\mathrm{a}}\right)$ & 0.006 & 0.012 & $<.001 *$ & $<.001^{*}$ \\
\hline \multirow[t]{3}{*}{ Gender } & Men & $28.7 \%$ & $37.6 \%$ & $18.2 \%$ & $27.4 \%$ \\
\hline & Women & $18.6 \%$ & $31.9 \%$ & $13.2 \%$ & $24.0 \%$ \\
\hline & $p\left(\right.$ Chi $^{2}$-test $\left.^{\mathrm{a}}\right)$ & $<.001 *$ & $0.004 *$ & 0.021 & 0.043 \\
\hline
\end{tabular}

Note. ${ }^{a}$ The Chi ${ }^{2}$-test in 2008 was conducted differentiating between 7 age categories (16-29-year-olds were divided into 3 age categories, the other categories were the same as in 2016). Data is weighted. *significant $(p<.05)$ after Bonferroni correction. Accounting for 10 comparisons based on the same dataset (2008 vs. 2016; all comparisons in Tables 5-7), the $p$-value has to be < 0.005 for the test result to be statistically significant according to the original level of significance $(p<.05)$.

When comparing anger expression by age and gender simultaneously (Table 6), we find that gender differences are mostly significant within the group of older people but not for younger people. In case of anger as older aggressor, the gender difference was significant in 2008 but not in 2016.

Table 6: Involvement in anger expression as victim and aggressor by gender separately for people below 40 and above.

\begin{tabular}{llllll}
\hline & & \multicolumn{3}{c}{ Victim } & \multicolumn{2}{c}{ Aggressor } \\
& & 2008 & 2016 & 2008 & 2016 \\
\hline $16-39$ & men & $30.4 \%$ & $38.9 \%$ & $21.4 \%$ & $32.7 \%$ \\
& women & $25.1 \%$ & $36.8 \%$ & $21.4 \%$ & $29.3 \%$ \\
& $p$ (Chi ${ }^{2}$-test) & .154 & .293 & .546 & .179 \\
\hline $40+$ & men & $27.4 \%$ & $36.7 \%$ & $16.4 \%$ & $24.5 \%$ \\
& women & $14.1 \%$ & $28.5 \%$ & $7.6 \%$ & $20.2 \%$ \\
& $p$ (Chi ${ }^{2}$-test) & $<.001^{*}$ & $.001^{*}$ & $.001^{*}$ & .042 \\
\hline
\end{tabular}

Note. Data is weighted. *significant $(p<.05)$ after Bonferroni correction.

With regard to regional differences (see Table 7), we find in both samples that more road rage is expressed in the Capital Region of Denmark as compared to all other regions. The regional differences are only significant in the 2016 sample and seem to have increased. Almost every third individual in the densely populated Capital Region has expressed anger in traffic within the past 12 months, while it was only every fifth in the sparsely populated Northern Region of Denmark. 
Table 7: Involvement in anger expression as victim and aggressor by the five Danish regions.

\begin{tabular}{lcccc}
\hline & \multicolumn{2}{c}{ Victim } & \multicolumn{2}{c}{ Aggressor } \\
Region & 2008 & 2016 & 2008 & 2016 \\
\hline Capital & $28.5 \%$ & $41.0 \%$ & $16.5 \%$ & $30.8 \%$ \\
Zealand & $23.2 \%$ & $34.0 \%$ & $14.5 \%$ & $24.0 \%$ \\
Southern & $21.5 \%$ & $32.9 \%$ & $17.5 \%$ & $25.3 \%$ \\
Central & $21.9 \%$ & $29.8 \%$ & $14.3 \%$ & $22.0 \%$ \\
Northern & $18.6 \%$ & $30.9 \%$ & $14.4 \%$ & $20.6 \%$ \\
\hline$p$ (Chi ${ }^{2}$-test) & 0.199 & $.001^{*}$ & 0.873 & $.005^{*}$ \\
\hline
\end{tabular}

Note. Data is weighted. *significant $(p<.05)$ after Bonferroni correction.

\subsection{Attributed reasons for anger expression in traffic}

Participants in the 2016 survey were asked to assess the reasons for other people's anger expressions in traffic and for their own anger expression. As Table 8 shows, people differ in the reasons attributed to themselves and others. While others' behaviour is mostly attributed to that others' cannot control their anger (64\% agree or strongly agree to this item), that they want to show the other road user clearly that he/she made a mistake (65\%), and that they use them as an outlet for their anger (59\%), own behaviour is in most cases attributed as a reaction of getting frightened (57\%), while only a minority interpret own aggressive behaviour as not being able to behave (5\%) or not being able to control anger (9\%).

Table 8: Attributed reasons for others’ and own anger expression

\begin{tabular}{|c|c|c|c|c|c|}
\hline & \multicolumn{2}{|c|}{$\begin{array}{l}\text { Attributed reasons for others' } \\
\text { anger expression }\end{array}$} & \multicolumn{2}{|c|}{$\begin{array}{l}\text { Reasons for own anger } \\
\text { expression }\end{array}$} & \multirow{2}{*}{$\begin{array}{c}\text { T-test for } \\
\text { paired } \\
\text { samples } \\
t\end{array}$} \\
\hline & Mean & SD & Mean & SD & \\
\hline They/I got frightened & 3.27 & 0.99 & 3.48 & 1.08 & $-8.29 *$ \\
\hline Show me/others that I/they made a mistake & 3.64 & 0.87 & 3.05 & 1.10 & $21.41^{*}$ \\
\hline Use me/them to let off steam & 3.61 & 0.87 & 2.37 & 1.02 & $45.39 *$ \\
\hline Unable to behave themselves/myself & 3.51 & 0.94 & 1.94 & 0.96 & $53.32 *$ \\
\hline Unable to control their/my anger & 3.74 & 0.89 & 2.05 & 1.05 & $55.75 *$ \\
\hline
\end{tabular}

Note. $1=$ totally disagree; 5 = totally agree; $N=2000$, Data is weighted. *significant $(p<.05)$ after Bonferroni correction. Accounting for 5 comparisons, the $p$-value has to be $<0.01$ for the test result to be statistically significant according to the original level of significance $(p<.05)$

When comparing how men and women, younger and older people explain other's and own anger expression, we find several significant differences; the most pronounced differences are that women more often explain their own behaviour with getting frightened, while young people more often want to show others that they made a mistake or use others to let off steam (see Table 9). 
Table 9: Attributed reasons for others' and own anger expression by gender and age

\begin{tabular}{|c|c|c|c|c|c|c|c|c|c|c|c|c|}
\hline & \multicolumn{6}{|c|}{ Attributed reasons for others' anger expression } & \multicolumn{6}{|c|}{ Reasons for own anger expression } \\
\hline & $\begin{array}{c}\text { Men } \\
(M)\end{array}$ & $\begin{array}{l}\text { Wome } \\
\mathrm{n}(M)\end{array}$ & $P$ & $\begin{array}{l}<40 \\
(M)\end{array}$ & $\begin{array}{l}40+ \\
(M)\end{array}$ & $p$ & $\begin{array}{l}\text { Men } \\
(M)\end{array}$ & $\begin{array}{l}\text { Wome } \\
\mathrm{n}(M)\end{array}$ & $P$ & $\begin{array}{l}<40 \\
(M)\end{array}$ & $\begin{array}{l}40+ \\
(M)\end{array}$ & $p$ \\
\hline $\begin{array}{l}\text { They/I got } \\
\text { frightened }\end{array}$ & 3.18 & 3.36 & $.000 *$ & 3.35 & 3.21 & .002 & 3.21 & 3.75 & $.000 *$ & 3.49 & 3.48 & .734 \\
\hline $\begin{array}{l}\text { Show me/others } \\
\text { that I/they made a } \\
\text { mistake }\end{array}$ & 3.55 & 3.73 & $.000 *$ & 3.63 & 3.65 & .693 & 3.05 & 3.05 & .921 & 3.20 & 2.96 & $.000^{*}$ \\
\hline $\begin{array}{l}\text { Use me/them to let } \\
\text { off steam }\end{array}$ & 3.54 & 3.67 & $.001 *$ & 3.59 & 3.62 & .425 & 2.35 & 2.39 & .329 & 2.54 & 2.27 & $.000^{*}$ \\
\hline $\begin{array}{l}\text { Unable to behave } \\
\text { themselves/myself }\end{array}$ & 3.59 & 3.42 & $.000 *$ & 3.40 & 3.57 & $.000^{*}$ & 2.01 & 1.86 & $.001^{*}$ & 2.00 & 1.90 & .017 \\
\hline $\begin{array}{l}\text { Unable to control } \\
\text { their/my anger }\end{array}$ & 3.77 & 3.71 & .135 & 3.64 & 3.80 & $.000 *$ & 2.12 & 1.97 & $.001 *$ & 2.19 & 1.96 & $.000^{*}$ \\
\hline
\end{tabular}

their/my anger

Note. 1 = totally disagree; 5 = totally agree; $N=2000$. Data is weighted. *significant $(p<.05)$ after Bonferroni correction. Accounting for 40 comparisons in Tables 9-11, the $p$-value has to be $<0.001$ for the test result to be statistically significant according to the original level of significance $(p<.05)$.

When looking into differences based on education level (see Table 10), we find that higher educated people show higher agreement to all suggested explanations for others' behaviour. With regard to own behaviour, people with the lowest and highest level of education interestingly agree more than people with medium level of education that they cannot behave and cannot control their rage, while people with higher education agree more that they got frightened. There are no relevant differences with regard to income.

Table 10: Attributed reasons for others' and own anger expression by level of education

\begin{tabular}{lccccccccccc}
\hline & \multicolumn{3}{c}{ Attributed reasons for others' anger expression } & \multicolumn{6}{c}{ Reasons for own anger expression } \\
& $\begin{array}{l}\text { basic } \\
\text { education }\end{array}$ & $\begin{array}{c}\text { low } \\
\text { further } \\
\text { education }\end{array}$ & $\begin{array}{c}\text { medium } \\
\text { further } \\
\text { education }\end{array}$ & $\begin{array}{c}\text { long-term } \\
\text { further } \\
\text { education }\end{array}$ & $p$ & $\begin{array}{c}\text { basic } \\
\text { educatio } \\
\mathrm{n}\end{array}$ & $\begin{array}{c}\text { low } \\
\text { further } \\
\text { education }\end{array}$ & $\begin{array}{c}\text { medium } \\
\text { further } \\
\text { education }\end{array}$ & $\begin{array}{c}\text { long- } \\
\text { term } \\
\text { further } \\
\text { education }\end{array}$ & $p$ \\
\hline $\begin{array}{l}\text { They/I got } \\
\text { frightened }\end{array}$ & 3.20 & 3.27 & 3.28 & 3.28 & .818 & 3.22 & 3.39 & 3.55 & 3.62 & $.000^{*}$ \\
$\begin{array}{l}\text { Show me/others } \\
\text { that I/they made a } \\
\text { mistake }\end{array}$ & 3.36 & 3.62 & 3.69 & 3.71 & $.000^{*}$ & 3.05 & 2.98 & 3.02 & 3.25 & $.001^{*}$ \\
$\begin{array}{l}\text { Use me/them to let } \\
\text { off steam }\end{array}$ & 3.33 & 3.63 & 3.64 & 3.64 & $.000^{*}$ & 2.42 & 2.37 & 2.32 & 2.45 & .214 \\
$\begin{array}{l}\text { Unable to behave } \\
\text { themselves/myself }\end{array}$ & 3.40 & 3.54 & 3.47 & 3.58 & .107 & 2.11 & 1.88 & 1.89 & 2.04 & .002 \\
$\begin{array}{l}\text { Unable to control } \\
\text { their/my anger }\end{array}$ & 3.52 & 3.74 & 3.74 & 3.83 & .002 & 2.24 & 2.04 & 1.97 & 2.12 & .004 \\
\hline
\end{tabular}

Note. $1=$ totally disagree; 5 = totally agree; $N=1986$. Data is weighted. *significant $(p<.05)$ after Bonferroni correction.

When looking separately at people who were only victim or aggressor or both (see Table 11), we find that people who were aggressors only, more often than the other groups interpret others' aggressive behaviour as getting frightened and less often as not being able to behave or control themselves. By their own aggressive behaviour, aggressors (no matter if also victim or not) more 
often want to show others that they made a mistake but they also more often agree that they just got frightened. People that are both victim and aggressor agree more that they cannot control their anger and cannot behave.

Table 11. Attributed reasons for others' and own aggressive behaviours by anger expression within past 12 month

\begin{tabular}{|c|c|c|c|c|c|c|c|c|c|c|}
\hline & \multicolumn{4}{|c|}{$\begin{array}{c}\text { Attributed reasons for others' aggressive } \\
\text { behaviours; Mean agreement }\end{array}$} & \multicolumn{6}{|c|}{$\begin{array}{l}\text { Reasons for own aggressive behaviours; } \\
\text { Mean agreement }\end{array}$} \\
\hline & $\begin{array}{c}\text { neither } \\
\text { nor }\end{array}$ & $\begin{array}{c}\text { victim } \\
\text { only }\end{array}$ & $\begin{array}{l}\text { aggressor } \\
\text { only }\end{array}$ & $\begin{array}{l}\text { victim } \\
\text { and } \\
\text { aggressor }\end{array}$ & $p$ & $\begin{array}{l}\text { neither } \\
\text { nor }\end{array}$ & $\begin{array}{l}\text { victim } \\
\text { only }\end{array}$ & $\begin{array}{l}\text { aggressor } \\
\text { only }\end{array}$ & $\begin{array}{l}\text { victim } \\
\text { and } \\
\text { aggressor }\end{array}$ & $p$ \\
\hline $\begin{array}{l}\text { They/I got } \\
\text { frightened }\end{array}$ & 3.32 & 3.07 & 3.53 & 3.16 & $.000 *$ & 3.40 & 3.49 & 3.68 & 3.66 & $.000^{*}$ \\
\hline $\begin{array}{l}\text { Show me/others that } \\
\text { I/they made a } \\
\text { mistake }\end{array}$ & 3.60 & 3.66 & 3.67 & 3.72 & .141 & 2.88 & 2.82 & 3.58 & 3.58 & $.000 *$ \\
\hline $\begin{array}{l}\text { Use me/them to let } \\
\text { off steam }\end{array}$ & 3.60 & 3.70 & 3.52 & 3.57 & .110 & 2.40 & 2.18 & 2.33 & 2.48 & $.000^{*}$ \\
\hline $\begin{array}{l}\text { Unable to behave } \\
\text { themselves/myself }\end{array}$ & 3.50 & 3.67 & 3.26 & 3.48 & $.000 *$ & 1.96 & 1.76 & 1.87 & 2.07 & $.000^{*}$ \\
\hline $\begin{array}{l}\text { Unable to control } \\
\text { their/my anger }\end{array}$ & 3.73 & 3.92 & 3.46 & 3.72 & $.000 *$ & 2.03 & 1.82 & 2.14 & 2.29 & $.000^{*}$ \\
\hline
\end{tabular}

Note. Data is weighted. *significant $(p<.05)$ after Bonferroni correction.

When comparing the agreement to the different reasons for others and own aggression with the actual expressed aggression according to DAX scores (see Table 12), we find that interpreting others behaviour as letting off steam is related to constructive anger expression. With regard to the motives of own behaviour, wanting to show others clearly that they made a mistake and not being able to control the rage is related to higher total anger expression, which is in line with the results of Table 9. While there are other significant relations, they are quite low and should not be interpreted.

Table 12 Correlation (Pearson) of attributed reason for others' and own aggression with level of anger expression according to DAX scores.

\begin{tabular}{|c|c|c|c|c|}
\hline & \multicolumn{2}{|c|}{$\begin{array}{c}\text { Attributed reasons for others' aggressive } \\
\text { behaviours }\end{array}$} & \multicolumn{2}{|c|}{ Reasons for own aggressive behaviours } \\
\hline & $\begin{array}{l}\text { Total aggressive } \\
\text { expression (DAX) }\end{array}$ & $\begin{array}{l}\text { Constructive } \\
\text { expression (DAX) }\end{array}$ & $\begin{array}{l}\text { Total aggressive } \\
\text { expression (DAX) }\end{array}$ & $\begin{array}{c}\text { Constructive } \\
\text { expression (DAX) }\end{array}$ \\
\hline They/I got frightened & .024 & $.114^{* * *}$ & $.049 *$ & $.113^{* * *}$ \\
\hline $\begin{array}{l}\text { Show me/others that I/they } \\
\text { made a mistake }\end{array}$ & .045 & $.159^{* * *}$ & $.258^{* * *}$ & $-.118^{* * *}$ \\
\hline Use me/them to let off steam & -.034 & $.215^{* * *}$ & $.153^{* * *}$ & $-.070 * *$ \\
\hline $\begin{array}{l}\text { Unable to behave } \\
\text { themselves/myself }\end{array}$ & -.034 & $.126^{* * *}$ & $.137 * * *$ & $-.141^{* * *}$ \\
\hline $\begin{array}{l}\text { Unable to control their/my } \\
\text { anger }\end{array}$ & -.045 & $.182^{* * *}$ & $.188^{* * *}$ & $-.174 * * *$ \\
\hline
\end{tabular}

Note. ${ }^{*} p<.05 ; * * p<.01 ; * * * p<.001$. Data is weighted. 


\section{Discussion}

The aim of this study was twofold: First, to provide an overview of the development of anger expression in Denmark in the last decade and to see to what extent possible changes differ in specific sub-groups of the population. Second, to investigate how people explain their own anger expression and the anger expression of others, to what extent both attributions are related to each other, to demographic variables and to anger expression as driver.

With regard to a possible increase in anger expression, the results are inconclusive. On the one hand, we identified a significant increase from $24 \%$ of people involved in anger expression incidents in 2005 to 35\% in 2016. On the other hand, the frequency of anger expression decreased. Thus, in 2016 more people were exposed to anger expression but with a lower frequency compared to 2005. Not surprisingly, the prevalence as well as the increase of anger expression was higher in the densely populated Capital Region of Denmark. This may be related to higher levels of traffic congestions as previous studies show that anger expression is influenced by traffic congestion (e.g., Shinar, 1998; Shinar \& Compton, 2004), which has increased during the last decade. According to the Danish Road Directorate (2017), travelled kilometres on Danish roads increased by $11 \%$ from 2010 to 2016. While regional differences increased over time, gender differences decreased and were generally only significant for older people, indicating an assimilation of gender roles. Recent studies on anger expression and gender roles show that feminine traits are related to more adaptive/constructive behaviours and lower aggressive expression (Sullman, Paxion, \& Stephens, 2017; Sullman, Stephens, \& Hill, 2017). A decrease in feminine traits in women and/or an increase in feminine traits in men could explain the decreasing differences between genders and should be subject to further investigation.

With regard to age, the increase of aggression is lowest in the age group up to 30 years of age, which indicates that younger people today are less aggressive, when taking the general increase of road anger into account. There is also some indication for a cohort effect according to which the earlier youngest age group remained the most aggressive group of road users when growing older. This would be interesting to examine further, in particular in relation to the effects of demographic change, which should in principle lead to a decrease of road anger expression because of a higher share of older people. However, if people keep their actual levels of road anger expression when they age, this may not be the case. Longitudinal studies are required to examine whether changes of road anger expression are more likely to be explained by cultural and social factors, including 
changing gender roles and a higher acceptance of rudeness in society or traffic-related and infrastructural factors.

Whether the identified increase in anger expression is unique for Denmark is difficult to assess, as it has not been possible to find similar recent studies from other countries. However, in the Canadian study by Vanlaar et al. (2008) a decrease from 2002 - 2006 was identified, which is similar to the decease we identified from 2005 - 2008. Thus, although further studies are needed to verify this, other countries may have experienced a similar development of road anger expression.

With regard to the attributed reasons for anger expression, we identified significant differences for anger expressed by other road users and by oneself. In line with a previous study (Lennon, Watson, Arlidge, \& Graham, 2011) anger expressed by other road users was mostly attributed to individual characteristic such as a lack of ability to control anger, whereas this was the second least often attributed reason for own anger expression. This indicates that drivers interpret the underlying reason behind a given behaviour differently depending on who performs the behaviour. As the pattern in the distributed reasons was similar regardless if the driver was a victim and/or aggressor with regard to anger expression, this further indicates that the interpretation of the reasons behind a given behaviour may not always be correct. It is possible that the anonymity of the individual road users, which is known to reinforce road anger (Ellison-Potter, Tay, \& Watson, 2001; O’Brien, Tay, \& Watson, 2004), also mediates the misinterpretation of the motives behind the behaviour of other road users. In addition, the limited access to social cues (e.g. facial expressions) may also increase the chances of misunderstanding the intentions and behaviours of other drivers.

The data available in this study does not allow for conclusions about the reasons for possible misinterpretations of the motives behind anger expression. However, as the interpretation of a behaviour influences the behavioural response, efforts to support non-hostile attributions to the behaviour of other road users may be a relevant approach to reduce anger expression in traffic. More specifically, a relevant approach could be cognitive interventions aiming to change the cognitive pattern towards being more tolerant and forgiving. This is further supported by the result that "want to clearly show me/others that I/they made a mistake" was among the most frequently attributed reasons for other road users' anger expression. It indicates that anger expression among other road users is often interpreted as a deliberate, intended and hostile behaviour. In terms of prevention this is important as it indicates a need for efforts to support drivers in actively choosing constructive behavioural reactions to what they may interpret as hostile anger expression. A relevant approach to achieve this could be behavioural training programmes allowing drivers to 
rehearse constructive behavioural reactions. It is also interesting to look at the differences between aggressive road users and less aggressive or constructive road users. The wish to show other road users clearly that they made a mistake is significantly related to aggressive behaviour. But aggressive road users also seem aware of their lack of being able to control themselves as they often see this as a reason for their own aggressive behaviour but less often as a reason for others'. This insight may signal willingness to change and responsiveness to campaigns aiming for a reduction of road anger. An overview of the few intervention programmes aiming to reduce road anger is provided by Deffenbacher (2016). Most of these interventions are targeted at drivers with severe anger expression problems. Yet, cognitive and behavioural training aiming to develop constructive behavioural expressions in traffic could also be used as part of the standard licensing program for new drivers.

Results indicate that more people are victims of road anger expression than aggressors. According to Vanlaar et al. (2008), a majority of victims is not surprising, as aggressors can be assumed to repeat their aggression, thereby increasing the number of victims. However, the results of the present study suggest that the reasons attributed to own and other road users' anger expression may also be of key importance for the self-reported frequency of road traffic anger. In the present study, anger expression of other people was mostly attributed to a "lack of ability to control their anger" whereas own anger expression was mostly attributed to situational factors such as getting frightened. Consequently, people may be less likely to interpret own behaviour as anger expression and thus less inclined to see themselves as aggressors, whereas other people who are not aware that a given behaviour was caused by fear may interpret the behaviour as aggression and themselves as a victim. In accordance with Kaiser et al. (2016) such attributional error may lead to a higher number of self-reported road anger victims compared with road anger aggressors. In addition, social desirability may play a role.

A minority (8\%) of the participants were aggressors only and had thus not been a victim of anger expression by other road users during the past 12 months. Being aggressor only could be assumed to indicate an angry and hostile approach to other road users as the aggression of the aggressorsonly obviously was not a response to aggression by other road users. However, results indicate that this is not the case as aggressors-only were more likely to explain aggression by others as a result of being frightened rather than not being able to control their anger. Similarly, although admitting that they want to show other road users that they made a mistake, they more often explained their own behaviour by being frightened. 
In conclusion the results of this study indicate an increase in the prevalence of anger expression by means of "yelling" and "threatening" over the past decade. They further clearly show that knowledge on reasons behind apparent anger expression is of key importance for the development of measures to reduce anger expression in traffic. Although the results could indicate increasing levels of anger among road users, results also indicate that being frightened is a key mediating factor. Further studies into the specific interactions causing the fear are relevant, but the present results already clearly indicate the need to address the issue when developing measures to reduce road traffic anger expression.

\section{Limitations and future research}

This study is based on self-reported data and as such subject of potential biases such as selfselection bias and social desirability (e.g. Lajunen \& Summala, 2003). Data in 2016 were collected based on an online survey, while data in the two proceeding studies were collected by telephone interviews, which can be regarded as a limiting factor for data comparability. However, as access to the conventional telephone network has decreased over the years and internet access has strongly increased (by 2015 92\% of the population in Denmark had an officially registered and accessible email address, Lauterbach, 2015), we think that the switch in data collection methods is justifiable. Similar as in other studies based on online panels (Craig, Hays, Pickard, Cella, Revicki, \& Reeve, 2013) participants were higher educated than the general population. But as education level is not significantly related to anger expression (Møller \& Haustein, 2017), we consider this sample bias as negligible. Yet, a longitudinal survey based on partly the same participants and exactly the same questionnaire and sampling procedure would surely allow for stronger conclusions, also in terms of potential cohort effects and is suggested for future studies on the development of road anger expression.

In addition, it would be interesting to include additional variables that could explain changes over time, such as driving frequency, attitudes and social norms towards road safety and aggressive expression, and gender roles.

\section{Acknowledgements}

The authors would like to acknowledge the financial and professional support by the Danish Ministry of Transport, Building and Housing and the Danish Road Safety Council. The authors 
would also like to acknowledge the support provided by the Danish Crime Prevention Council regarding the surveys conducted in 2005 and 2008.

\section{References}

Berdoulat, E., Vavassori, D., \& Sastre, M. T. M. (2013). Driving anger, emotional and instrumental aggressiveness, and impulsiveness in the prediction of aggressive and transgressive driving. Accident Analysis and Prevention, 50, 758-767.

Bogdan, S. R., Mairean, C., \& Havârneanu, C. E. (2016). A meta-analysis of the association between anger and aggressive driving. Transportation Research Part F, 42, 350-364.

Britt, T. W., \& Garrity, M. J. (2006). Attributions and personality as predictors of the road rage response. British Journal of Social Psychology, 45, 127-147.

Burns, R. G., \& Katovich, M. A. (2003). Examining road rage/aggressive driving. Media depicting and prevention strategies. Environment and Behaviour, 35, 621-636.

Craig, M., Hays, R. D., Pickard, A. S., Cella, D., Revicki, D. A., \& Reeve, B. B. (2013). Comparison of US panel vendors for online surveys. Journal of Medical Internet Research, 15, e260.

Crick, N. R., \& Dodge, K. A. (1996). Social information-processing mechanisms in reactive and proactive aggression. Child Development, 67, 993-1002.

Danish Road Directorate (2017). http://www.vejdirektoratet.dk/DA/viden_og_data/statistik/trafikken\%20i\%20tal/hvordan_udv ikler_trafikken_sig/Sider/default.aspx

Dahlen, E. R., Martin, R. C., Ragan, K., \& Kuhlman, M. M. (2005). Driving anger, sensation seeking, impulsiveness, and boredom proneness in the prediction of unsafe driving. Accident Analysis and Prevention, 37, 341-348.

Deffenbacher, J. L., Oetting, E.R., Lynch, R.S. (1994). Development of a driving anger scale. Psychological reports, 74, 83-91.

Deffenbacher, J.L., Lynch, R. S., Oetting, E. R, \& Swaim, R.C. (2002). The driving anger expression inventory: a measure of how people express their anger on the road. Behaviour Research and Therapy, 40, 717-737.

Deffenbacher, J. L., Deffenbacher, D. M., Lynch, R. S., \& Richards, T. L. (2003). Anger, aggression, and risky behavior: a comparison of high and low anger drivers. Behaviour Research and Therapy 41, 701-718. 
Deffenbacher, J. L., Lynch, R. S., Filetti, L. B., Dahlen, E. R., \& Oetting, E. R. (2003). Anger, aggression, risky behaviour, and crash-related outcomes in three groups of drivers. Behaviour Research and Therapy, 41, 701-718.

Deffenbacher, J. L. (2016). A review of interventions for the reduction of driving anger. Transportation Research Part F, 42, 411-421.

DKR - Det Kriminalpræventive Råd (2009). Konflikter i trafikken. Udvalgte resultater fra undersøgelse af konflikter i trafikken. http://www.dkr.dk/media/8184/konflikter-itrafikken.pdf.

DST \& DKR - Danmark Statisktik \& Det Kriminalpræventive Råd (2005). Interviewundersøgelse blandt borgerne i Danmark om konflikter i trafikken. http://www.dkr.dk/media/8222/trafikkonflikter-2005.pdf.

Ellison-Potter, P., Bell, P., \& Deffenbacher, J. (2001). The Effects of Trait Driving Anger, Anonymity, and Aggressive Stimuli on Aggressive Driving Behavior. Journal of Applied Social Psychology, 31, 431-443.

Energistyrelsen (2016). Telestatistik, første halvår 2016. https://ens.dk/sites/ens.dk/files/Tele/telestatistik_-_foerste_halvaar_2016.pdf

Feng, Z., Lei, Y., Liu, H., Kumfer, W.J., Zhang, W., Wang, K., \& Lu, S. (2016). Driving anger in China: A case study on professional drivers. Transportation Research Part F, 42, 255-266.

Galovski, T. E., \& Blanchard, E. B. (2004). Road rage: a domain for psychological intervention? Aggression and Violent Behavior, 9, 105-127.

González-Iglesias, B., Gómez-Fraguela, J. A., \& Luengo-Martín, M. A. (2012). Driving anger and traffic violations: Gender differences. Transportation Research Part F, 15, 404-412.

Hennesy, D. A. (2016). Are narcissists really angrier drivers? An examination of state driving anger among narcissistic subtypes. Transportation Research Part F, 42, 267-275.

Kaiser, S., Furian, G., \& Schlembach, C. (2016). Aggressive behaviour in road traffic - findings from Austria. Transportation Research Procedia, 14, 4384-4392.

Lajunen, T., \& Parker, D. (2001). Are aggressive people aggressive drivers? A study of the relationship between self-reported general aggressiveness, driver anger and aggressive driving. Accident Analysis and Prevention, 33, 243-255.

Lajunen, T., \& Summala, H. (2003). Can we trust self-reports of driving? Effects of impression management on driver behaviour questionnaire. Transportation Research Part F, 6, 97-101.

Lauterbach, T. (2015). It-anvendelse i befolkningen 2015. Retrieved from the Statistics Denmark website: www.dst.dk/Publ/ItBefolkning. 
Lemerise, E.A., \& Arsenio, W.F. (2000). An integrated model of emotion processes and cognition in social information processing. Child Development, 71, 107-118.

Lennon, A., Watson, B., Arlidge, C., \& Fraine, G. (2011). 'You're a bad driver but I just made a mistake': attribution differences between the 'victims' and 'perpetrators' of scenario-based aggressive driving incidents. Transportation Research Part F, 14, 209-221.

Lennon, A., \& Watson, B. (2011). “Teaching them a lesson?” A qualitative exploration of underlying motivations for driver aggression. Accident Analysis and Prevention, 43, 22002208.

Li, F., Yao, X., Jiang, L., \& Li, Y. (2014). Driving anger in China: psychometric properties of the driving anger scale (DAS) and its relationship with aggressive driving. Personality and Individual Differences, 68, 130-135.

Møller, M., \& Haustein, S. (2017). Anger expression among Danish cyclists and drivers: A comparison based on mode specific anger expression inventories. Accident Analysis and Prevention, 108, 354-360.

Nesbit, S. M., Conger, J. C., \& Conger, A. J. (2007). A quantitative review of the relationship between anger and aggressive driving. Aggression and Violent Behaviour, 12, 156-176.

Novaco, R. W., Stokols, D., \& Milanesi, L. (1990). Objective and subjective dimensions of travel impedance as determinants of community stress. American Journal of Community Psychology, 18, 231-257.

O’Brien, S., Tay, R., \& Watson, B. (2004). Situational factors contributing to the expression of aggression on the roads. IATSS research, 28, 101-107.

Parker, D., Lajunen, T., \& Summala, H. (2002). Anger and aggression among drivers in three European countries. Accident Analysis and Prevention, 34, 229-235.

Precht, L., Keinath, A., \& Krems, J. F. (2017). Effects of driving anger on driver behaviour Results from naturalistic driving data. Transportation Research Part F, 45, 75 - 92.

Roberts, L.D., \& Indermaur, D. (2005). Social issues as media constructions: the case of 'road rage'. Crime Media Culture, 1, 301-321.

Rowden, P., Watson, B., Haworth, N., Lennon, A., Shaw, L., \& Blackman, R. (2016). Motorcycle riders' self-reported aggression when riding compared with car driving. Transportation Research Part F, 36, 92-103.

Shinar, D. (1998). Aggressive driving: the contribution of the drivers and the situation.

Transportation Research Part F, 1, 137-160. 
Shinar, D., \& Compton, R. (2004). Aggressive driving: an observational study of driver, vehicle, and situational variables. Accident Analysis and Prevention, 36, 429-437.

Smart, R. G., \& Mann, R. E. (2002). Is road rage a serious traffic problem? Traffic Injury Prevention, 3, 183-189.

Stephens, A. N., \& Sullman, M. J. M. (2014). Development of a short form of the driving anger expression inventory. Accident Analysis and Prevention, 72, 169-176.

Stephens, A. N., Trawley, S. L., \& Ohtsuka, K. (2016). Venting anger in cyperspace: selfentitlement versus self-preservation in \#roadrage tweets. Transportation Research Part F, 42, 400-410

Sullman, M. J. M., Stephens, A. N., \& Kuzu, D. (2013). The expression of anger amongst Turkish taxi drivers. Accident Analysis and Prevention, 56, 42-50.

Sullman, M. J. M. (2015). The expression of anger on the road. Safety Science, 72, 153-159.

Sullman, M. J., Paxion, J., \& Stephens, A. N. (2017). Gender roles, sex and the expression of driving anger. Accident Analysis and Prevention, 106, 23-30.

Sullman, M. J., Stephens, A. N., \& Hill, T. (2017). Gender roles and the expression of driving anger among Ukrainian drivers. Risk Analysis, 37, 52-64.

Vanlaar, W., Simpson, H., Mayhew, D., \& Robertson, R. (2008). Aggressive driving: A survey of attitudes, opinions and behaviors. Journal of Safety Research, 39, 375-381.

Wickens, C. M., Roseborough, J. E. W., Hall, R., \& Wiesenthal, D. L. (2013). Anger-provoking events in driving diaries: a content analysis. Transportation Research Part F, 19, 108-120.

Wickens, C. M., Mann, R. E., Lalomiteanu, A. R., \& Stoduto, G. (2016). Do driver anger and aggression contribute to the odds of a crash? A population-level analysis. Transportation Research Part F, 42, 389-399.

Yagil, D. (2001). Interpersonal antecedents of drivers' aggression. Transportation Research Part F, 4, 119-131.

Zhang, T., \& Chan, A. H. S. (2016). The association between driving anger and driving outcomes: A meta-analysis of evidence from the past twenty years. Accident Analysis and Prevention, 90, 50-62.

Zhang, T., Chan, A. H. S., Ba, Y., \& Zhang, W. (2016). Situational driving anger, driving performance and allocation of visual attention. Transportation Research Part F, 42, 376-388. 